鈴木友二, 岩永貞昭 : 蛇毒蛋白の研究 (第 8 報*1) マムシ毒, ハブ毒の L-アミノ酸酸化酵素の基質特異性について

Tomoji Suzuki and Sadaaki Iwanaga: Studies on Snake Venom. VIII. Substrate Specificitiy of L-Amino Acid Oxidase in Mamushi (Agkistrodon halys blomhoff BoIE) and Habu (Trimeresurus okinavensis BOulenger) Venoms.

(Faculty of Pharmacy, Kyoto University*2)

Substrate specificity of L-amino acid oxidase in the venoms of Japanese "Mamushi" (Agkistrodon halys blomhoffi) and "Habu" (Trimeresurus okinavensis) was examined with 46 kinds of amino acid. The enzymes from these snake venom were stronger than that of cobra venom and were especially marked in oxidizing arginine and isoleucine. This specificity to these two amino acids has not been found in any literature, either in Japan or abroad, or in cobra venom.

(Received October 12, 1959)

Lーアミノ酸酸化酵素の活性は動物組織や細菌では極めて弱く，蛇毒でのみ著しく強い，とのためこの酵素源と しては蛇毒が専ら用いられ， $\alpha$-アミノ酸からの $\alpha$-ケト酸の製造1)，D-アミノ酸中に夾雑する微量のL-アミノ酸の 除去 ${ }^{2}$, ア アミノ酸の立体配位の決定 ${ }^{3)}$ など実験室的な用途はひろい。Lーアミノ酸酸化酵素は毒蛇の種類によりとの 性質，基質特異性などが多少相違し，外国産の二，三の蛇毒の基質特異性については報告4,5)されているが，日本 産のものについての報告を見ない。著者等はすでに吸着実験6) やクロマトグラフィー7のときなどのLーアミノ酸 酸化酵素の挙動について報告したが，今回はその基質特異性をしらべた。

蛇毒を長期間保存すると $\mathrm{L}$ アアミノ酸酸化酵素は失活し，この失活は主に助酵素部分 FADの光分解によると考 完られるが，このとき同時にアポ蛋白部分も変性するらしく，活性の減少した蛇毒にFAD を添加しても回復を 見ない8．したがつてできるだけ新しい蛇毒の使用が望まれるが，日本で新しいものの入手し易いマムシ毒，ハブ 毒はその外観も黄色が強く FAD 含量も高い上うに見られ，実際 L-アミノ酸酸化酵素の活性は一般に外国産のも のに勝るとも劣らない。

Lーアミノ酸酸化酵素のアポ蛋白と FAD との結合は非常に強く, Singer 等9) む, また著者等も FAD と活性 なアポ蛋白部分との分離に成功していないまた著者等のマムシ毒での吸着実験やクロマトグラフィーの操作で も，FAD とアポ蛋白との結合はこわされずに結合型の屯屯他の諸酵素とよく分画され，乙かもこれら操作の結 果, 全酵素単位は約 3 倍近くに上昇し粗毒中には L-アミノ酸酸化酵素の阻害物質が存在することが推察された6). したがつて蛇毒の高価なことや，との中にホスホジェステラーゼ，レシチナーゼ A など生化学の研究上有用な酵 素が存在することを考えるとき，他酵素と分画して後に Lーアミノ酸酸化酵素を利用し他酵素を別に活用すること が望なれる。

基質特暴性 まず基質特異性を調ベるに先立つて酔素活性の測定条件を二, 三検討した.マムシ毒, ハブ毒, コブラ毒の Lーアミノ酸酸化酵素の pH-活性曲線を作成し Fig. 1 の結果をえた。また基質濃度をかえた場合，高 濃度の基質によつて活性低下が見られる(Fig. 2). したがつて各種アミノ酸を基質にする際は溶解度の低い場合を 考光に入れて通常 $5 \times 10^{-4} M$ のアミノ酸を用いることにした.

*1 第 7 報 鈴木, 岩永, 佐竹：本誌 80,861(1960). *2 Yoshida-konoe-cho, Sakyo-ku, Kyoto。

1) A. Meister : J. Biol. Chem. 197, 309(1952).

2) J.R. Parikh, J.P. Greenstein, M. Winitz, S. M. Birnbaum : J. Am. Chem. Soc. 80, 953(1958).

3) W.S. Fones: Arch. Biochem. Biophy. 36, 86(1952).

4) E. Frieden, K. Dittmer, L. T. Hsu : J. Biol. Chem. 192, 425(1951).

5) E. A. Zeller : Advances in Enzymology 8, 495(1948).

6) 鈴木, 岩永：本誌 78, 362(1958). 7) 岩永, 河内：本誌 79, 582(1959).

8) 岩永, 楊, 河内: 本誌 78, 791(1958).

9) T.P. Singer, E. B. Kearney : Arch. Biochem. 29, 190(1950). 

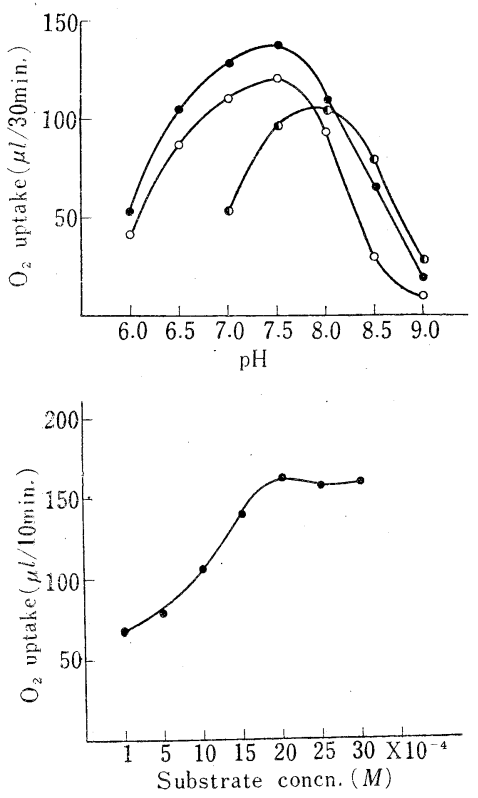

Fig. 1.

pH-Activity Curves

Conditions : Reaction mixture contained $1 \mathrm{mg}$. of venom, $5 \times 10^{-4} M$ L-leucine, and $0.2 M$ Tris buffer $(\mathrm{pH} 7.0 \sim 9.0)$ or $0.2 M$ veronal buffer $(\mathrm{pH} 6.0 \sim 6.5)$ in a total volume of $2.2 \mathrm{cc}$. $\left(37.5^{\circ}\right.$, air)

- - Mamushi (Agkistrodon halys blomhoffi)

-— Habu (Trimeresurus okinavensis)

D—C Cobra (Naja naja atra)

Fig. 2.

Effect of Substrate Concentration on Enzyme Activity

Conditions: Reaction mixture contained $1 \mathrm{mg}$. of Mamushi venom, $0.2 M$ Tris buffer $(\mathrm{pH} 7.2)$, and the indicated amounts of $\mathrm{L}_{\mathrm{H}}$ leucine

(final concn.) in a total volume of 2.2 cc. $\left(37.5^{\circ}\right.$, air $)$

外国産蛇毒との比較のため, Zeller ${ }^{10)}$ やBender 等 ${ }^{11)}$ の用いたアミノ酸をできるだけ集め，それに 8 種のア ミノ酸同族体を加えて計 46 種で実験した，著者等の測定した結果を表中の I， I に，また比較のためにBender 等10) のコブラ毒についての結果を III に記した. な挔, 表中の $\mathrm{O}_{2}$ uptake $\mu \mathrm{L}$ は Bender 等の catalase 存在 下の場合の值に補正したので, 実測值の $1 / 2$ の值で表わされている.

Table I. Relative Rate of Oxidation of Various Amino Acids by L-Amino Acid Oxidase in Japanese Snake Venoms

\section{Amino Acids}

DL-Alanine

DL- $\beta$-Alanine

DL-2-Aminobutyric acid

DL-2-Aminovaleric acid

DL-2-Aminocaproic acid

DL-2-Aminolauric acid

DL-Valine

L-Leucine

DL-Isoleucine

DL-2-Aminoisobutyric acid

DL-2-Aminoisoheptanoic acid

L-Glutamic acid

DL-Aspartic acid

L-Asparagine

L-Tyrosine

DL-Bromotyrosine

DL-Iodotyrosine

DL-Phenylglycine

DL-Phenylalanine
$\mathrm{O}_{2}$ uptake, $\mu \mathrm{L} / \mathrm{mg}$. venom $/ \mathrm{hr}$.

$\begin{array}{ccc}\text { Mamushi } & \text { Habu } & \begin{array}{c}\text { Cobra } \\ (\text { I })\end{array} \\ 8 & (\Pi) & \left.\text { (from Bender, } \text { et }{ }^{11}{ }^{11}\right) \\ 0 & 8 & 0 \\ 121 & 0 & 0 \\ 154 & 63 & 31 \\ 127 & 204 & 74 \\ 0 & 133 & 0 \\ 0 & 0 & 0 \\ 165 & 0 & 77 \\ 21 & 163 & 0 \\ 0 & 76 & \\ 132 & 0 & \\ 0 & 98 & 0 \\ 0 & 0 & 0 \\ 7 & 0 & \\ 218 & 42 & \\ 109 & 228 & \\ 98 & 121 & \\ 16 & 105 & \\ 177 & 12 & \\ & 192 & \end{array}$

10) E. A. Zeller, A. Maritz : Helv. Chim. Acta 27, 365(1945).

11) A. E. Bender, H. A. Krebs : Biochem. J. 46, 210(1950). 


\begin{tabular}{|c|c|c|c|}
\hline DL-Phenylserine & 0 & 0 & 0 \\
\hline DL-Tryptophan & 128 & 79 & 76 \\
\hline L-Histidine & 12 & 12 & 0 \\
\hline L-Proline & 0 & 0 & 0 \\
\hline DL-Serine & 0 & 0 & 0 \\
\hline DL-Threonine & 0 & 0 & 0 \\
\hline DL-Homoserine & 44 & 56 & \\
\hline L-Arginine & 77 & 165 & 32 \\
\hline L-Canavanine & 96 & 122 & \\
\hline DL-Citrulline & 119 & 145 & \\
\hline DL-Ornithine & 0 & 0 & 0 \\
\hline DL-Lysine & 0 & 0 & 0 \\
\hline DL-Homolysine & 0 & 0 & \\
\hline DL-Diaminobutyric acid & 0 & 0 & \\
\hline DL-Methionine & 168 & 279 & 94 \\
\hline DL-Ethionine & 14 & 24 & \\
\hline DL-Propionine & 0 & 0 & \\
\hline DL-Buthionine & 0 & 0 & \\
\hline L-Cysteine & 143 & 136 & \\
\hline DL-Homocysteine & 191 & 176 & \\
\hline L-Cystine & 0 & 0 & 0 \\
\hline DL-Jienkolic acid & 0 & 0 & \\
\hline DL-S-Methylcysteine & 179 & 209 & \\
\hline DL-S-Ethylcysteine & 157 & 157 & \\
\hline DL-S-Butylcysteine & 12 & 0 & \\
\hline DL-S-Methylmethionine & 0 & 0 & \\
\hline
\end{tabular}

Conditions : Reaction mixture contained $1 \mathrm{mg}$. of the venom, $0.2 M$ Tris buffer (pH 7.2 ), and $5 \times 10^{-4} M \mathrm{~L}-$ or DL-amino acid in a total volume of $2.2 \mathrm{cc}$. $\left(37.5^{\circ}\right.$, air).

脂肪族アミノ酸についていえば，一般に直鎖アミノ酸は枝鎖アミノ酸に比べて酸化され易く，マムシ毒，ハブ 毒とも炭素数 5 個のノルバリンをもつともよく酸化する・コブラ毒についての報告では炭素数 6 個のアミノ酸が もつとも酸化され易く，炭素数 4 以下のアミノ酸や側鎖をもつ鎖状了ミノ酸であるイソロイシンは殆んど酸化さ れていない。

またヒドロキシアミノ酸であるセリン，スレオニン，ジアミノ酸であるリジン，オルニシン，ジカルボン酸で あるグルタミン酸, アスパラギン酸などは全く酸化されないが, 末端に $\mathrm{H}_{2} \mathrm{~N}-\mathrm{C}(=\mathrm{NH})-\mathrm{NH}-\mathrm{r}$ (基(ルギニン), $\mathrm{H}_{2} \mathrm{~N}-$ $\mathrm{CONH}$-基(シトルリン), $\mathrm{H}_{2} \mathrm{NCO}$-基 (アスパラギン) などをるつアミノ酸はよく酸化された。これらの結果はアル ギニンの場合を除けば III のコブラ毒についての報告とほぼ一致する。、ムシ毒, ハブ毒ともアルギニンを酸化 するが，ことにハブ毒についての $Q_{\mathrm{O}_{2}}$ 值は外国文献にあるいずれの蛇毒よりも著しく大さい。

芳香族をむつチロシン, フェニルアラニントリプトプァンなどはいずれも極めて酸化され易くすずててのア ミノ酸を通じて同程度に酸化されたものはメチオニンだけである。

含硫アミノ酸の場合はメチオニンや S-メチルシステインがよく酸化され，エチオニンは急激泜低下する，炭素 数の 1 個少ない化合物で同じような比較を試みたが S-エチルシステインはS-メチルシステインと殆んぞ同程度 に酸化された．末端に SH基をもつシステイン，ホモシステインが酸化されるのに，それらの $\mathrm{SH}$ 基が $\mathrm{OH}$ 基汇 かわつただけのセリン，ホモセリンが殆えど酸化されていないことは基質と酵素の結合を考光るときの参考にな ろう.

以上を要約するとマムシ毒，八ブ毒のょーアミノ酸酸化酵素活性はュブラ䓯に和けるより強く，かつマムシ毒， ハブ毒は多種のアミノ酸に作用し，とくにアルギニン，イソロイシンの両者をよく酸化するが，この二つのアミ ノ酸に対する親和性はコブラ毒の及ならず外国文献のいずれにも見られなかつたものである.

な洛 Table I の実験に用いた蛇毒は抗血清製造用のものである. その後, 採取して間もないマムシ毒を著者が 凍結した標品について同じような測定を行なつたが $Q_{0_{2}}$ の值に著しい差はみとめなかつた。また測定には たは DLーアミノ酸を使用したが Dーアミノ酸による酵素活性の阻害は考慮する要はないと考学る。 


\section{実 験 の 部}

蛇、 マムシ毒, 八ブ毒は抗血清製造用の乾燥標品で, またコブラ毒は名城大学田中哲之助博士の採取し たものを用いた。

アミノ酸 Table I に示した製品は, いずれも著者等の教室で微生物定量用の培地に用いているものである.

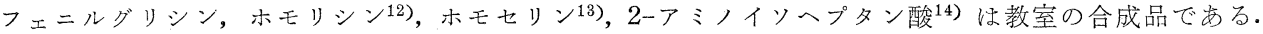

L-アミノ酸酸化酵素活性の測定、マムシ毒または八ブ毒 $2 \mathrm{mg}$ をとれぞれ $1 \mathrm{cc}$ の蒸留水にとかして酵素液 とした。ワールブルグセルの主室に，酵素液 $0.5 \mathrm{cc}, 0.2 M$ トリス緩衝液 $(\mathrm{pH} 7.2) 1.0 \mathrm{cc}$, 副室に $20 \% \mathrm{KOH}$ $0.2 \mathrm{cc}$ と汇紙切片, 側室に $5 \times 10^{-3} M$ のアミノ酸をそれぞれ加えて全量 $2.2 \mathrm{cc}$ として, $37.5^{\circ}$ に調製した恒温槽 に浸し $3 \mathrm{~min}$ 振温後，基質液を主室に移し $30 \mathrm{~min}$ の $\mathrm{O}_{2}$ 消費を測定した。 $Q_{\mathrm{O}_{2}}$ はロイシンを基質とした場合， マムシ毒で 165 ，ハブ毒で 163 であうた。

終りに蛇毒を分与下さつた名城大学薬学部田中哲之助博士ならびに武田薬工研究所 大村栄之助博士に厚く御 礼申し上げ尔す。また本研究の費用の一部は財団法人蓬庵社からの奨励金によつた。ここに深謝致します。

京都大学薬学部

12) S. Takagi, K. Hayashi : Chem. Pharm. Bull. (Tokyo) 7, 183(1959).

13) K. Hayashi : Ibid. 7, 187(1959). $\quad$ 14) S. Takagi, K. Hayashi : Ibid. 7, 96(1959).

UDC 547.833.9.07

新美仁作：1-(Bromobenzy1)-1,2,3,4-tetrahydroisoquinoline 誘導体の脱ブロム化反応

Jinsaku Niimi : Studies on the Debromination of 1-(Bromobenzyl)1,2,3,4-tetrahydroisoquinoline Derivatives.

(Faculty of Pharmacy, Kyoto University*1)

Three kinds of 1-(x-bromobenzyl)-1,2,3,4-tetrahydroisoquinoline derivative, with bromine in different position in each, were reduced with zinc dust and acetic acid. It was found that bromine atoms in 3 - and 4 -positions remain inert and only that in 2 -position undergoes reductive debromination. Reduction with metallic sodium in liquid ammonia effects quantitative debromination in all these positions.

(Received October 14, 1959)

著者は 1-(2-bromobenzy1)-2-methy1-6,7-dimethoxy-1,2,3,4-tetrahydroisoquinoline ${ }^{1)}$ ( I ) の合成過程で 1(2-bromobenzy1)-6,7-dimethoxy-3,4-dihydroisoquinoline (VI) を常法にしたがつて50\% 酢酸中亜鉛末とと もに油浴中加熱還流させ，反応成績体を修酸塩として捕捉元素分析を行なつたところ，予想される 1-(2-bromobenzy1)-6,7-dimethoxy-1,2,3,4-tetrahydroisoquinoline (Ш) oxalate の組成とは異なつた組成を示すことを知 り，この成績体が還元反応によつて一部脱ブロム化反応の起こつた成績体を含有するものと考光，この修酸塩を 再び遊離塩基とした後，さらに50\% 酢酸一亜鉛末と加熱還流した。ここに得られた成績体は予期したと和り<smiles>[R4]c1ccc(CC2c3c(OC)cc4c(OC)c3CCN([R1])[C@H]2C4)c([R4])c1[R4]</smiles>

( I ) $\mathrm{R}_{1}=\mathrm{CH}_{3}, \mathrm{R}_{2}=\mathrm{Br}, \quad \mathrm{R}_{3}, \mathrm{R}_{4}=\mathrm{H}$

() $\mathrm{R}_{1}, \mathrm{R}_{3}, \mathrm{R}_{4}=\mathrm{H}, \mathrm{R}_{2}=\mathrm{Br}$

(III) $\mathrm{R}_{1}, \mathrm{R}_{2}, \mathrm{R}_{3}, \mathrm{R}_{4}=\mathrm{H}$

(IV) $\mathrm{R}_{1}=\mathrm{CH}_{3}, \mathrm{R}_{2}, \mathrm{R}_{4}=\mathrm{H}, \mathrm{R}_{3}=\mathrm{Br}$

(V) $\mathrm{R}_{1}=\mathrm{CH}_{3}, \mathrm{R}_{2}, \mathrm{R}_{3}=\mathrm{H}, \mathrm{R}_{4}=\mathrm{Br}$

(VII) $\mathrm{R}_{1}=\mathrm{CH}_{3}, \mathrm{R}_{2}, \mathrm{R}_{3}, \mathrm{R}_{4}=\mathrm{H}$

(IX) $\mathrm{R}_{1}, \mathrm{R}_{2}, \mathrm{R}_{3}=\mathrm{H}, \mathrm{R}_{4}=\mathrm{Br}$

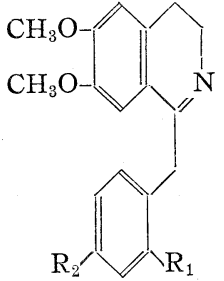

(VI) $\mathrm{R}_{1}=\mathrm{Br}, \mathrm{R}_{2}=\mathrm{H}$

(VII) $\mathrm{R}_{1}=\mathrm{H}, \mathrm{R}_{2}=\mathrm{Br}$

*1 Yoshida-konoe-chō, Sakyo-ku, Kyoto.

1) 新美：本誌 80, 123(1960). 